\title{
Tumour necrosis factor and PI3-kinase control oestrogen receptor alpha protein level and its transrepression function
}

\author{
P Bhat-Nakshatri' ${ }^{1,5}$, RA Campbell ${ }^{2}$, NM Patel ${ }^{2}$, TR Newton ${ }^{2}$, AJ King ${ }^{1,3,6}$, MS Marshall $^{1,3,7}$, Ali $^{4}$ and \\ H Nakshatri*, ${ }^{*, 2,3,5}$
}

'Walther Oncology Center, Indiana University School of Medicine, Indianapolis, IN 46202, USA; ${ }^{2}$ Department of Surgery, Indiana University School of Medicine, Indianapolis, IN 46202, USA; ${ }^{3}$ Department of Biochemistry and Molecular Biology, Indiana University School of Medicine, Indianapolis, IN 46202, USA; ${ }^{4}$ Department of Cancer Medicine, Imperial College School of Medicine, Hammersmith Hospital, London WI 2 ONN, UK; ${ }^{5}$ Walther Cancer Institute, Indianapolis, IN 46208, USA

\begin{abstract}
Oestrogen receptor alpha $(E R \alpha)$ is an oestrogen-activated transcription factor, which regulates proliferation and differentiation of mammary epithelial cells by activating or repressing gene expression. ER $\alpha$ is a critical prognostic indicator and a therapeutic target for breast cancer. Patients with tumours that express higher level of ER $\alpha$ have better prognosis than patients with tumours that are ER $\alpha$ negative or express lower level of ER $\alpha$. Better prognosis in ER $\alpha$-positive patients is believed to be due to repression of proinvasive gene expression by $E R \alpha$. Oestrogen receptor alpha represses gene expression by transrepressing the activity of the transcription factors such as nuclear factor-kappaB or by inducing the expression of transcriptional suppressors such as MTA3. In this report, we show that $E R \alpha$ transrepresses the expression of the proinvasive gene interleukin 6 (IL-6) in ER $\alpha$-negative MDA-MB-23I breast cancer cells stably overexpressing ER $\alpha$. Using these cells as well as ER $\alpha$-positive MCF-7 and ZR-75-I cells, we show that tumour necrosis factor alpha (TNF $\alpha$ ) and the phosphatidylinositol-3-kinase (PI3-kinase) modulate transrepression function of ER $\alpha$ by reducing its stability. From these results, we propose that TNF $\alpha$ expression or PI3-kinase activation lead to reduced levels of ER $\alpha$ protein in cancer cells and corresponding loss of transrepression function and acquisition of an invasive phenotype.

British Journal of Cancer (2004) 90, 853-859. doi: I0.1038/sj.bjc.660 I54I www.bjcancer.com
\end{abstract}

(c) 2004 Cancer Research UK

Keywords: oestrogen receptor, tumour necrosis factor, PI3-kinase, IL-6, transrepression

Oestrogen receptor alpha $(\mathrm{ER} \alpha)$ expression status is of prognostic significance for breast cancer. Breast cancer patients with the highest levels of $\mathrm{ER} \alpha$ protein have a $90 \% 5$-year survival rate and display very few p53 mutations. Patients with lower ER $\alpha$ levels have $\sim 45 \%$ 5-year survival and higher p53 mutation rates. The survival rate in these patients is similar to patients with a subset of $\mathrm{ER} \alpha$-negative breast cancer (Sorlie et al, 2001). Better prognosis in $\mathrm{ER} \alpha$-positive breast cancer patients can partly be attributed to their response to antihormone therapy (Ali and Coombes, 2002). However, because patients with higher rather than lower ER $\alpha$ protein have better prognosis, it is likely that some of the ER $\alpha$ regulated genes suppress invasion and metastasis of breast cancer. Consistent with this possibility, it was shown recently that ER $\alpha$ dependent expression of metastasis associated protein 3 (MTA3) is required to prevent invasive growth of breast cancer cells (Fujita et al, 2003). Furthermore, a recent microarray study has shown

*Correspondence: Dr H Nakshatri, R4-202, Indiana Cancer Research Institute, 1044 West Walnut Street, Indianapolis, IN 46202, USA; E-mail: hnakshat@iupui.edu

${ }^{6}$ AJ King's current address: GlaxoSmithKline, Collegeville, PA, USA

${ }^{7}$ MS Marshall's current address: Eli Lilly and Company, Indianapolis, IN, USA

Received 23 June 2003; revised 15 October 2003; accepted 5 November 2003 that among $\sim 400$ genes regulated by ER $\alpha$ /oestrogen in MCF-7 cells, majority of them $(70 \%)$ are downregulated (Frasor et al, 2003). Some of the downregulated genes are known to be involved in invasion and homing of metastatic cancer cells (Muller et al, 2001).

Oestrogen receptor alpha is an oestrogen-activated transcription factor, which modulates gene expression by binding to oestrogen response elements (ERE) in the responsive promoter and through protein-protein interactions (Mangelsdorf et al, 1995; Di Croce et al, 1999). Oestrogen receptor alpha contains a central DNA binding domain (DBD), C-terminal ligand binding domain (LBD), as well as ligand-dependent activation function (AF-2) and Nterminal ligand-independent activation function (AF-1). Upon binding to oestrogen, ER $\alpha$ homodimers bind to ERE in the responsive gene promoters and activate gene expression. In addition, ER $\alpha$ homodimers activate non-ERE containing promoters by interacting with transcription factors such as SP-1 and AP1 (Gaub et al, 1990; Paech et al, 1997; Dong et al, 1999). Transactivation by ER $\alpha$ involves ligand-dependent recruitment of coactivators, which serve as an intermediate between the receptor and the RNA polymerase II transcription complex (Horwitz et al, 1996; Glass and Rosenfeld, 2000). Although binding of oestrogen to $\mathrm{LBD}$ is essential for complete activation of $\mathrm{ER} \alpha$, phosphorylation by extracellular signal-activated kinases is thought to play a role in oestrogen-dependent and oestrogen-independent activity of ER $\alpha$ (Ali et al, 1993; Le Goff et al, 1994). Recently, a novel cell-type 
specific nongenomic action of $\mathrm{ER} \alpha$ involving oestrogen-dependent association of $\mathrm{ER} \alpha$ with phosphatidylinositol-3-kinase (PI3-kinase) leading to activation of the cell survival kinase AKT has also been reported (Simoncini et al, 2000). In addition, ER $\alpha$ localised in the plasma membrane has been shown to activate the MAP kinase pathway and contribute to growth regulation of breast cancer cells (Filardo et al, 2000; Marquez and Pietras, 2001; Razandi et al, 2003).

Transrepression of gene expression through protein-protein interaction is also a critical function of $E R \alpha$. For example, inhibition of GATA-1-mediated transcription by $\mathrm{ER} \alpha$ is responsible for suppression of erythroid differentiation by oestrogen (Blobel et al, 1995). The protective effect of oestrogen against sepsis is believed to be due to the suppression of proinflammatory gene expression (Schroder et al, 1998; Evans et al, 2002). Similarly, $\mathrm{ER} \alpha$-dependent repression of nuclear factor kappa B (NF- $\kappa \mathrm{B})$ activity is important for maintaining bone density (Jilka et al, 1992; Pottratz et al, 1994; Stein and Yang, 1995). Evans et al (2002) have identified several NF- $\kappa$ B-regulated genes that are repressed by $\mathrm{ER} \alpha$, which include antiapoptotic proteins $\mathrm{GADD} 45 \beta$, apoptosis inhibitor 2, A20 and NF- $\kappa$ B p105. A recent report suggested that $\mathrm{ER} \alpha$ at higher levels reduces cancer cell growth and angiogenesis by inhibiting the expression of vascular endothelial growth factor (Ali et al, 2001). Furthermore, it was reported that unliganded and liganded $\mathrm{ER} \alpha$ reduce cancer cell migration and invasion, through a mechanism that involves protein-protein interaction (Platet et al, 2000). Unlike the case of the glucocorticoid receptor (GR) where transrepression function is well characterised (Nissen and Yamamoto, 2000), the mechanism of ER $\alpha$-mediated transrepression is not completely understood. Antagonism of NF- $\kappa \mathrm{B}$ activity has been used as a model system to understand ER $\alpha$-mediated transrepression. Repression of NF- $\kappa \mathrm{B}$ activity by $\mathrm{ER} \alpha$ is cell type specific (Cerillo et al, 1998). Both the DBD and LBD of $\mathrm{ER} \alpha$ are essential for efficient repression of NF- $\kappa \mathrm{B}$ activity (Stein and Yang, 1995; Valentine et al, 2000). It is suggested that ER $\alpha$ interacts directly with the Rel-homology domains (RHD) of the NF- $\kappa \mathrm{B}$ subunits, p50 and p65, thereby interfering with the transcriptional activity of DNA-bound NF- $\kappa$ B (Stein and Yang, 1995). Apart from inhibition through direct protein-protein interaction, competition for the limiting amount of common coactivators such as SRC-1 and $\mathrm{p} 300 / \mathrm{CBP}$ is suggested to play a role in ER $\alpha$-dependent repression of NF- $\kappa \mathrm{B}$ activity, although studies with $\mathrm{ER} \alpha$ harbouring mutations in its transactivation domain fail to support such a mechanism (Sheppard et al, 1999; Harnish et al, 2000; Valentine et al, 2000).

The goals of this study were to determine whether ER $\alpha$ transrepresses the expression of interleukin 6 (IL-6), a cytokine that is linked to breast cancer cell invasion and motility as well as resistance to chemotherapy (Tamm et al, 1991; Conze et al, 2001), and to identify signalling pathways that may modulate transrepression by altering the stability of ER $\alpha$. Using the ER $\alpha$-negative breast cancer cell line MDA-MB-231 stably overexpressing ER $\alpha$, we show that ER $\alpha$ transrepresses tumour necrosis factor alpha (TNF $\alpha$ )-inducible expression of IL-6. We also show that TNF $\alpha$ and PI3-kinase pathway modulate transrepression by reducing the stability of ER $\alpha$.

\section{MATERIALS AND METHODS}

\section{Generation of ER $\alpha$-overexpressing cells}

MCF-7, ZR-75-1 and MDA-MB-231 cells were purchased from the American Type Culture Collection (ATCC, Manassas, VA, USA). The cDNA encoding ER $\alpha$ was cloned into the EcoRI site of the retroviral vector LxSN (pLxSN-ER $\alpha$ ) (Miller and Rosman, 1989). Packaging of retrovirus and infection of MDA-MB-231 were performed as described previously (Newton et al, 1999). Briefly,
AM1 2 cells were transfected with $\mathrm{pLxSN}$ or $\mathrm{pLxSN}-\mathrm{ER} \alpha$ expression vector and selected in media containing $600 \mu \mathrm{g} \mathrm{ml}^{-1} \mathrm{G} 418$. G418resistant colonies were pooled and media supernatant with virus was used for infecting MDA-MB-231 cells. MDA-MB-231 cells were incubated with viral supernatant for $2 \mathrm{~h}$ in the presence of $8 \mu \mathrm{g} \mathrm{ml}^{-1}$ polybrene. The transduced cells were grown in the presence of $\mathrm{G} 418\left(1 \mathrm{mg} \mathrm{ml}^{-1}\right)$. Individual G418-resistant colonies were isolated and ER $\alpha$ expression was measured by Western blotting. The constitutively active PI3-kinase expression vector (myr-PI 3-Kp110) was purchased from Upstate Biotechnology (Charlottesville, VA, USA). Constitutively active AKT (CA-AKT) and kinase-dead AKT (KD-AKT) have been described previously (Campbell et al, 2001). Cells were transfected with expression vectors using Lipofectamine 2000 transfection reagent as recommended by the manufacturer and analysed for ER $\alpha$ protein levels $48 \mathrm{~h}$ after transfection (Invitrogen, Carlsbad, CA, USA).

\section{Northern blot analysis}

Total RNA was prepared using the RNAeasy kit from Qiagen (Valencia, CA, USA). RNA was subjected to Northern blot analysis as previously described (Newton et al, 1999). Interleukin-6 cDNA was purchased from ATCC, whereas tomour necrosis factor receptor associated protein 1 (TRAF-1) cDNA has been described previously (Rothe et al, 1994).

\section{Western blot analysis}

Whole-cell extracts were prepared in radioimmunoassay buffer (RIPA; $50 \mathrm{~mm}$ Tris $\mathrm{pH} 7.5,0.25 \%$ sodium deoxycholate, $1 \%$ NP40, $150 \mathrm{~mm} \mathrm{NaCl}, 1 \mathrm{~mm}$ EDTA, $100 \mu \mathrm{m}$ sodium orthovanadate, $1 \mathrm{~mm}$ sodium fluoride, $1 \mathrm{mM} \quad \beta$-glycerophosphate, $0.5 \mathrm{~mm}$ PMSF, $2 \mu \mathrm{g} \mathrm{ml}^{-1}$ each of aprotenin, leupeptin and pepstatin) and subjected to Western blot analysis as previously described (Newton et al, 1999). Oestrogen receptor alpha antibody raised against B-domain of ER $\alpha$ was purchased from Chemicon (MAB463; Temecula, CA, USA), whereas $\beta$-actin antibody was from Sigma Chemicals (St Louis, MO, USA). MG132, PD98059, LY294002, PP2 and protein kinase A (PKA) inhibitor peptide were purchased from Calbiochem (San Diego, CA, USA), whereas TNF $\alpha$ was purchased from R\&D systems (Minneapolis, MN, USA). Cells were incubated with kinase inhibitors for $2 \mathrm{~h}$ before addition of TNF. 4Hydroxytamoxifen was purchased from Sigma Chemicals, whereas ICI182780 was purchased from Tocris (Ellisville, MO, USA).

\section{RESULTS}

\section{ER $\alpha$ reduces TNF $\alpha$-inducible IL- 6 but not TRAF-1 expression}

Previously, we reported constitutive NF- $\kappa$ B activation in the ER $\alpha$ negative breast cancer cell line MDA-MB-231, which correlated with increased expression of several NF- $\kappa \mathrm{B}$-inducible genes including IL-6, Mn-SOD, cIAP-2 and TRAF-1 (Patel et al, 2000). In addition, using transient transfection assays, we showed transrepression of NF- $\kappa \mathrm{B}$ activity by ER $\alpha$ in these cells (Nakshatri et al, 1997). To further characterise the transrepression function of $\mathrm{ER} \alpha$, we stably overexpressed $\mathrm{ER} \alpha$ in MDA-MB-231 cells using retrovirus-mediated gene transfer (Figure 1A). Oestrogen receptor alpha- 3 and $E R \alpha-6$ clones overexpress wild-type $\mathrm{ER} \alpha$, whereas $\mathrm{ER} \alpha-8$ and $\mathrm{ER} \alpha-9$ overexpress mutant $\mathrm{ER} \alpha$ (C530R), which cannot activate transcription of an ERE-containing reporter gene (data not shown). Cysteine 530 is within the recently identified KCK motif involved in intramolecular AF-1 and AF-2 interaction and this mutation reduces the affinity of ER $\alpha$ to oestrogen (E2) (Metivier et al, 2002). Cells expressing the mutant protein were used to evaluate transrepression independent of coactivator competition and by a mutant $E R \alpha$ with reduced affinity to $\mathrm{E} 2$. We compared the 
A
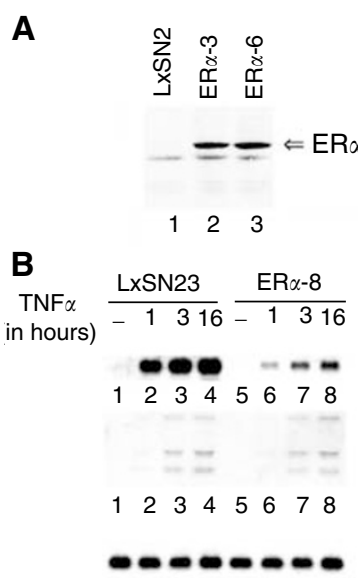

$\begin{array}{llllllll}1 & 2 & 3 & 4 & 5 & 6 & 7 & 8\end{array}$

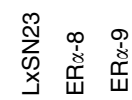

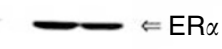

45

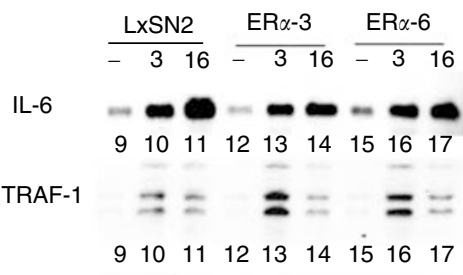

36B4

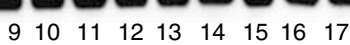

Figure I Oestrogen receptor alpha reduces TNF $\alpha$-inducible IL-6 but not TRAF-I expression in MDA-MB-23I cells. (A) Oestrogen receptor alpha expression in MDA-MB-23I cells. Oestrogen receptor alpha expression in cells transduced with retrovirus without the $E R \alpha$ coding sequence ( $L \times S N 2$ and $L \times S N 23$ ) or with the ER $\alpha$ coding sequence (ER $\alpha-3$, $E R \alpha-6, E R \alpha-8$ and $E R \alpha-9)$ was measured by Western blotting. Note that $E R \alpha-3$ and $E R \alpha-6$ cells express the wild-type receptor, whereas $E R \alpha-8$ and ER $\alpha-9$ cells express mutant receptor. (B) TNF $\alpha$-inducible IL-6 but not TRAF-I expression is lower in ER $\alpha$-overexpressing cells compared to control cells. Cells were treated with TNF $\alpha$ for the indicated times and IL-6 or TRAF-I expression was measured by Northern blot analysis. The same blot was reprobed with ribosomal protein gene 36B4 to ensure equal loading.

TNF $\alpha$-inducible expression of NF- $\kappa$ B-regulated genes IL- 6 and TRAF-1 in parental and ER $\alpha$-overexpressing cells. Inducible IL-6 but not TRAF-1 expression was lower in ER $\alpha-3$ and ER $\alpha-6$ cells compared to LxSN2 cells (Figure 1B). Similarly, IL-6 expression was lower in $\mathrm{ER} \alpha-8$ cells compared to LxSN23 cells (Figure 1B). Tumour necrosis factor alpha (TNF $\alpha$ )-inducible expression of cIAP-2, another NF- $\kappa$ B regulated gene, was not influenced by ER $\alpha$ suggesting that transrepression is promoter-context dependent (data not shown). Transrepression of Mn-SOD expression by ER $\alpha$ was observed with early passage cells but not in late passage cells, which suggests existence of inherent mechanism to overcome transrepression (data not shown). As mutant ER $\alpha(\mathrm{C} 530 \mathrm{R})$ transrepressed IL- 6 expression, sequestration of common limiting coactivators by ligand-activated $\mathrm{ER} \alpha$ is not necessary for transrepression.

\section{Pure antioestrogen ICI182780 reverses transrepression function of ER $\alpha$}

To further confirm the role of ER $\alpha$ in reducing TNF $\alpha$-inducible expression of IL- 6 in ER $\alpha$-overexpressing cells, we preincubated cells with E2, tamoxifen or ICI182780 for $2 \mathrm{~h}$ and measured IL-6 expression with or without TNF $\alpha$ treatment for $16 \mathrm{~h}$. Binding of E2 leads to activation and subsequent proteosome-dependent degradation of $\mathrm{ER} \alpha$ (Lonard et al, 2000). Previous studies have shown that binding of tamoxifen to ER $\alpha$ leads to stabilisation, whereas binding to ICI182780 leads to degradation of $E R \alpha$ without activation (Ali et al, 1993). Tamoxifen stabilised, whereas E2 and ICI182780 reduced ER $\alpha$ level in ER $\alpha-6$ cells (Figure $2 A$ ). The effect of various ligands on basal and TNF $\alpha$-inducible IL- 6 and TRAF-1 expression was examined. Oestrogen reduced basal IL- 6 expression in ER $\alpha-6$ cells compared to LxSN2 cells (Figure 2B, middle panel). This could be due to sequestration and subsequent degradation of common coactivators by ER $\alpha$. Interestingly, TNF $\alpha$-inducible IL- 6 expression was not influenced by E2. TNF $\alpha$-induced IL- 6 expres-

A
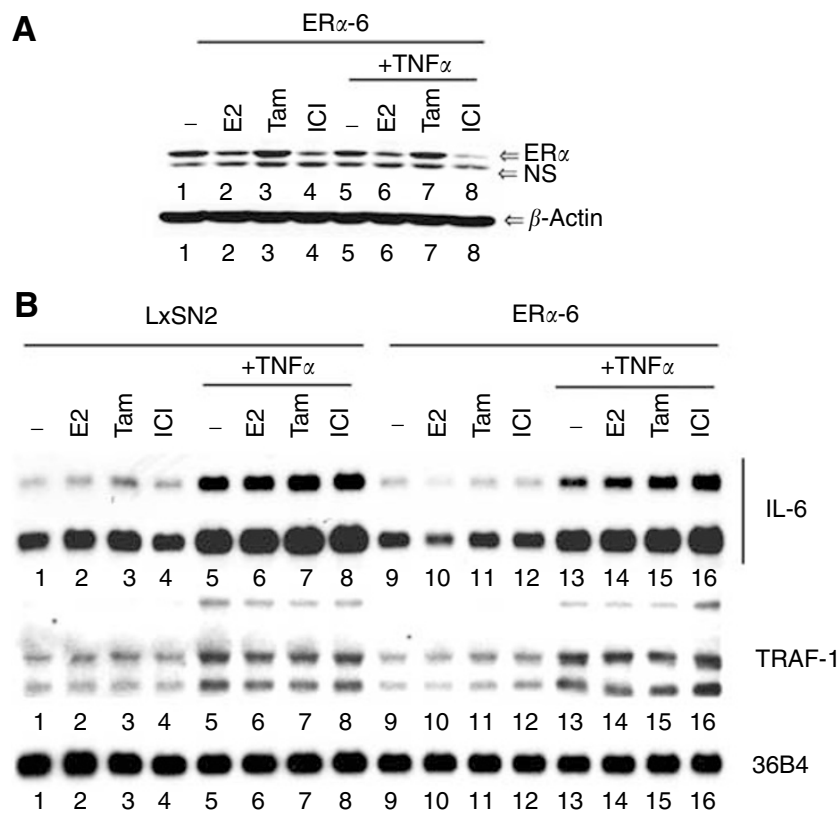

Figure 2 Pure antiestrogen IClI 82780 overcomes the transrepression function of ER $\alpha$. (A) Effect of oestrogen (E2), tamoxifen and ICII 82780 on the stability of ER $\alpha$. Oestrogen receptor alpha- 6 cells were treated with E2 $(10 \mathrm{nM})$, tamoxifen $(\mathrm{I} \mu \mathrm{M})$ or $\mathrm{ICl} / 82780$ (I00 nM) for $2 \mathrm{~h}$ followed by further incubation for $16 \mathrm{~h}$ with or without TNF $\alpha$. Oestrogen receptor alpha protein level was determined by Western blotting. The same blot was reprobed for $\beta$-actin. (B) ICII 82780 overcomes the transrepression function of ER $\alpha$. RNA from cells treated as above was subjected to Northern analysis with IL-6 or TRAF-I probe. Two exposures of the IL-6 blot are shown to highlight the effect of E2 on the basal IL-6 expression level in ER $\alpha-6$ cells.

sion was still lower in tamoxifen-treated ER $\alpha-6$ cells compared to tamoxifen-treated LxSN2 cells, suggesting that tamoxifen-bound $\mathrm{ER} \alpha$ is capable of transrepression, consistent with our previous transient transfection studies (Nakshatri et al, 1997). In contrast, TNF $\alpha$-inducible IL- 6 expression was similar in ICI182780-treated $\mathrm{ER} \alpha-6$ and LxSN2 cells (Figure 2B, compare lanes 8 and 16). Note that none of the ligands altered TNF $\alpha$-inducible TRAF-1 expression, which suggests that the observed effect of ligands on IL-6 expression is not due to toxicity. From these results, we conclude that $\mathrm{ER} \alpha$ is responsible for lower IL- 6 expression in ER $\alpha-6$ cells compared to LxSN2 cells, and antioestrogens that destabilize ER $\alpha$ can overcome ER $\alpha$-mediated suppression of IL- 6 expression.

\section{$\mathrm{TNF} \alpha$ reduces the stability of $\mathrm{ER} \alpha$ protein}

We consistently observed a lower level of $\operatorname{ER} \alpha$ in TNF $\alpha$-treated cells compared to untreated cells and a further enhancement of ICI182780-dependent degradation of $\mathrm{ER} \alpha$ by TNF $\alpha$ (Figure 2A). In early passage cells, TNF $\alpha$ reduced $\mathrm{ER} \alpha$ protein level by as much as $60 \%$ (data not shown). This raised the possibility that TNF $\alpha$ modulates transrepression function of $\mathrm{ER} \alpha$ by inducing its degradation. Towards this end, ER $\alpha-6$ and ER $\alpha-8$ cells with or without prior treatment with TNF $\alpha$ for $16 \mathrm{~h}$ were incubated with cyclohexamide to block protein synthesis. Cells were harvested at specific time intervals and ER $\alpha$ protein was measured by Western blotting. Oestrogen receptor alpha stability was much lower in cells pretreated with TNF $\alpha$ compared to untreated cells (Figure 3A). Oestrogen receptor alpha undergoes proteosome-mediated degradation in TNF $\alpha$-treated cells as the proteosomal inhibitor MG132 prevented ER $\alpha$ degradation (Figure 3B). Neither caspase inhibitors nor calpain inhibitors altered the stability of ER $\alpha$ under untreated and TNF $\alpha$-treated conditions (data not shown). Oestrogen receptor 


$$
\begin{aligned}
& \begin{array}{lllllllllllllllll}
\text { A } & \multicolumn{1}{c}{-\mathrm{TNF} \alpha} & \multicolumn{1}{c}{\mathrm{ER} \alpha-6} & \multicolumn{1}{c}{+\mathrm{TNF} \alpha} \\
\cline { 2 - 4 } & -2 & 3 & 4 & 5 & 6 & 7 & 8 & -2 & 3 & 4 & 5 & 6 & 7 & 8
\end{array}
\end{aligned}
$$

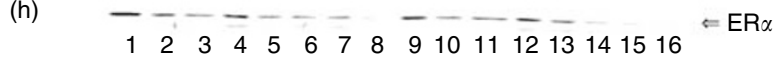

$$
\begin{aligned}
& \begin{array}{llllllllllllll}
1 & 2 & 3 & 4 & 5 & 6 & 7 & 8 & 9 & 10 & 11 & 121314 & 1516 & \Leftrightarrow \beta \text {-Actin }
\end{array} \\
& -\mathrm{TNF} \alpha \quad \mathrm{ER} \alpha-8 \quad+\mathrm{TNF} \alpha \\
& \text { Cyclohexamide } \begin{array}{rllllllllllll} 
& -1 & 2 & 3 & 4 & 5 & 6 & -1 & 2 & 3 & 4 & 5 & 6
\end{array} \\
& \text { (h) }
\end{aligned}
$$

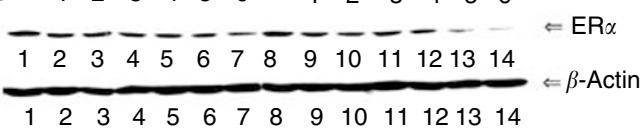

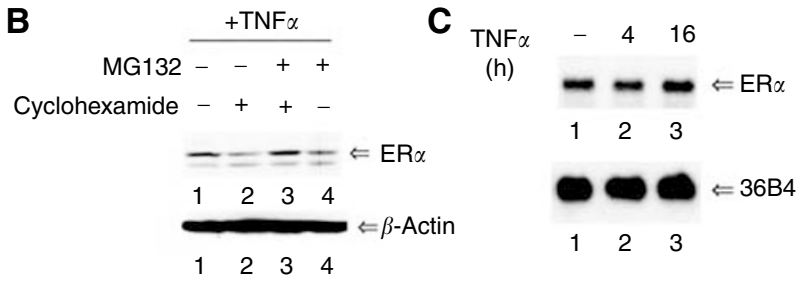

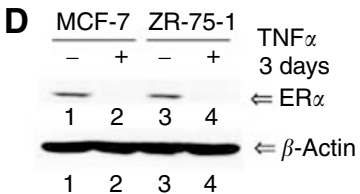

Figure $3 \mathrm{TNF} \alpha$ reduces stability of $E R \alpha$ protein. (A) Stability of $E R \alpha$ in untreated and TNF $\alpha$-treated cells. Untreated or TNF $\boldsymbol{\alpha}$-treated (for 16 h) $\mathrm{ER} \alpha-6$ and $\mathrm{ER} \alpha-8$ were exposed to cyclohexamide $\left(20 \mu \mathrm{g} \mathrm{ml} \mathrm{l}^{-1}\right)$, and cells were harvested at specific time intervals as indicated. Oestrogen receptor alpha protein was measured by Western blotting. Note reduced stability of ER $\alpha$ in TNF $\alpha$-treated cells. (B) Oestrogen receptor alpha undergoes proteosome-mediated degradation in TNF $\alpha$-treated cells. Oestrogen receptor alpha- 6 cells were first treated with TNF $\alpha$ for $16 \mathrm{~h}$. Subsequently, cells were incubated with cyclohexamide with or without MGI32 for $4 \mathrm{~h}$ and $E R \alpha$ protein levels were measured by Western blotting. (C) Tumour necrosis factor alpha has no effect on ER $\alpha$ transcript levels. Oestrogen receptor alpha transcripts were measured by Northern blotting. (D) Tumour necrosis factor alpha reduces endogenous ER $\alpha$ in MCF-7 and ZR75-I cells. Oestrogen receptor alpha protein levels were measured after 3 days of TNF $\alpha$ treatment.

alpha transcript levels were similar in untreated and TNF $\alpha$-treated cells, suggesting that the effect of $\mathrm{TNF} \alpha$ on $\mathrm{ER} \alpha$ is at the level of protein stability (Figure 3C). None of the effects of TNF $\alpha$ on ER $\alpha$ is due to TNF $\alpha$-induced apoptosis of MDA-MB-231 as these cells were resistant to $\mathrm{TNF} \alpha$ irrespective of $\mathrm{ER} \alpha$ overexpression (data not shown). Tumour necrosis factor alpha-induced destabilisation of $\mathrm{ER} \alpha$ was not restricted to MDA-MB-231 cells as TNF $\alpha$ reduced $\mathrm{ER} \alpha$ protein in ER $\alpha$-positive MCF-7 and ZR-75 cells (Figure 3D). Consequences of ER $\alpha$ degradation on transrepression in MCF-7 cells could not be studied because of lack of IL- 6 expression in these cells and their sensitivity to $\mathrm{TNF} \alpha$-induced apoptosis (data not shown).

\section{Phosphatidylinositol-3-kinase inhibitor LY294002 stabilises ER $\alpha$ protein in MDA-MB-231 cells and inhibits TNF $\alpha$-induced but not E2-induced degradation of ER $\alpha$ in MCF-7 cells}

MAPK, cyclin A/cdk2, AKT, RSK2, PKA, PAK1, p38 kinase and Src phosphorylate ER $\alpha$ (Ali et al, 1993; Lee and Bai, 2002; Wang et al, 2002). Phosphorylation leads to ligand-independent activation in most cases, and activated ER $\alpha$ undergoes coactivator-ubiquitindependent degradation (Lonard et al, 2000). Phophatidylinositol-
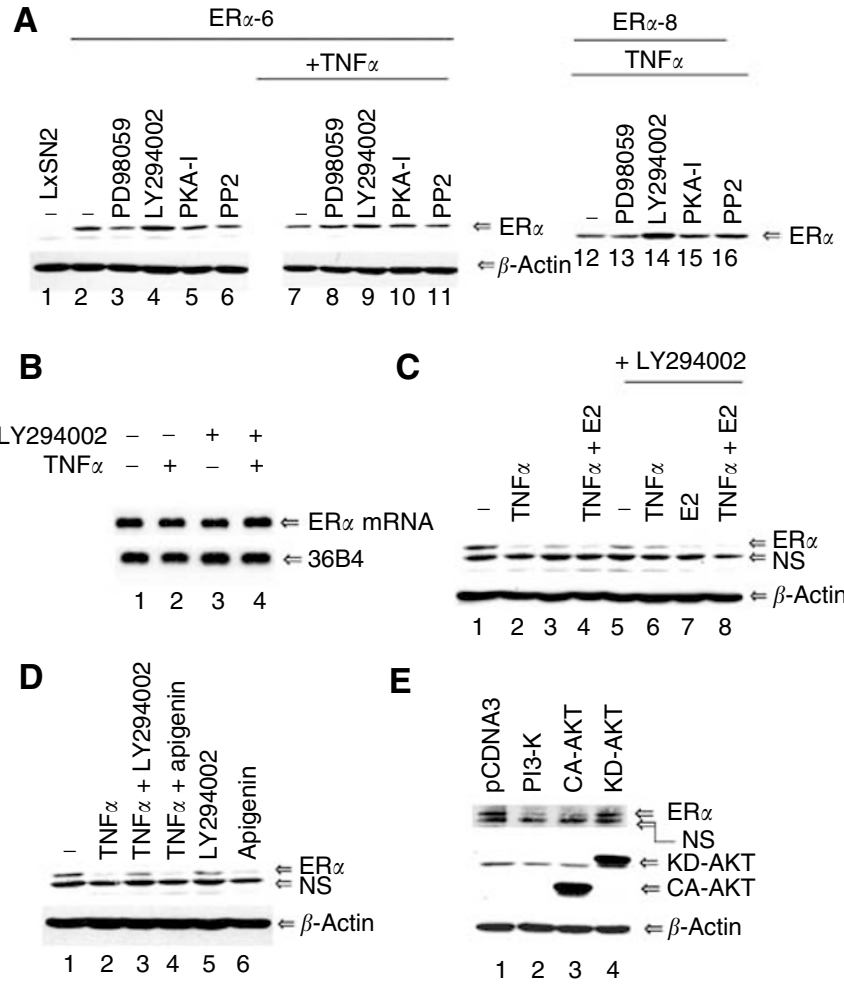

Figure 4 The PI3-kinase inhibitor LY294002 stabilises ER $\alpha$ protein. (A) The effect of MAP kinase, PI3-kinase, PKA and SRC kinase inhibitors on ER $\alpha$ stability. Oestrogen receptor alpha- 6 cells were incubated with inhibitors of MAP kinase (PD98059, $20 \mu \mathrm{M})$, Pl3-kinase (LY294002, $20 \mu \mathrm{M}), \quad$ PKA $(2.5 \mu \mathrm{M})$ or SRC (PP2, $5 \mu \mathrm{M})$ with or without TNF $\alpha$ for $16 \mathrm{~h}$. Oestrogen receptor alpha protein levels were measured by Western blotting. Similar results were obtained in TNF $\alpha$-treated ER $\alpha$-8 cells. (B) LY294002 has no effect on ER $\alpha$ transcripts as measured by Northern blot analysis. (C) LY294002 inhibits TNF $\alpha$-induced but not E2-induced ER $\alpha$ degradation in MCF-7 cells. MCF-7 cells were treated with the indicated reagents for 3 days and $E R \alpha$ protein levels were measured as described above. $\mathrm{NS}=$ nonspecific. (D) Apigenin, a casein kinase II inhibitor, fails to inhibit $\mathrm{TNF} \alpha$-induced degradation of $\mathrm{ER} \alpha$ in MCF-7 cells. (E) Constitutively active PI3-kinase and AKT (CA-AKT) but not kinase-dead AKT (KD-AKT) reduces the level of ER $\alpha$ in MCF-7 cells. Oestrogen receptor alpha levels in cells transfected with the indicated expression vectors using lipofectamine reagent for $48 \mathrm{~h}$ is shown.

3-kinase, which is upstream of AKT, as well as MAPK are constitutively active in MDA-MB-231 cells and may promote phosphorylation-dependent degradation of $\mathrm{ER} \alpha$ (Ma et al, 2001; Sliva et al, 2002). Consistent with this possibility, ER $\alpha$ showed ligand-independent activity in $\mathrm{ER} \alpha-3$ and $\mathrm{ER} \alpha-6$ cells (data not shown). To investigate whether any of these kinases determine the stability of $\mathrm{ER} \alpha$ and thus modulate transrepression function, we treated cells with various inhibitors for $16 \mathrm{~h}$ with or without TNF $\alpha$ treatment and measured ER $\alpha$ protein. The MAP kinase inhibitor PD98059, PKA inhibitory peptide or Src kinase inhibitor did not alter $\mathrm{ER} \alpha$ protein level in ER $\alpha-6$ cells (Figure $4 \mathrm{~A}$ ). In contrast, the PI3-kinase inhibitor LY294002 stabilised ER $\alpha$ protein under both untreated and $\mathrm{TNF} \alpha$-treated conditions. Similar results were obtained in ER $\alpha-8$ cells. Increase in ER $\alpha$ protein in LY294002treated cells was not due to increased transcription of ER $\alpha$ in LY294002-treated cells (Figure 4B). To further confirm the role of PI3-kinase on ER $\alpha$ stability, we examined the effect of LY294002 on $\mathrm{TNF} \alpha$-induced degradation of $\mathrm{ER} \alpha$ in MCF-7 cells. Although LY294002 reduced the basal ER $\alpha$ protein level possibly due to its effects on general transcription, it blocked TNF $\alpha$-induced but not E2-induced degradation of ER $\alpha$ (Figure 4C). Recent studies have 
shown that LY294002 inhibits both PI3-kinase and casein kinase II (Davies et al, 2000). We used apigenin, a casein kinase II inhibitor (Critchfield et al, 1997), to support our conclusion that PI3-kinase is involved in $\mathrm{TNF} \alpha$-induced degradation of $\mathrm{ER} \alpha$. Apigenin failed to inhibit $\mathrm{TNF} \alpha$-induced degradation of $\mathrm{ER} \alpha$ in MCF-7 cells (Figure 4D). In fact, apigenin on its own reduced ER $\alpha$ level. To further confirm the role of PI3-kinase in destabilisation of $\mathrm{ER} \alpha$, we transfected MCF-7 cells with constitutively active PI3-kinase and measured $\mathrm{ER} \alpha$ protein $48 \mathrm{~h}$ after transfection. Oestrogen receptor alpha protein levels were lower in cells transfected with PI3-kinase expression vector (Figure 4E). Similar results were obtained in 293 and MDA-MB-231 cells transfected with ER $\alpha$ and constitutively active PI3-kinase (data not shown). Activation of AKT alone is sufficient for PI3-kinase-mediated destabilisation of ER $\alpha$ as a constitutively active AKT (CA-AKT) but not kinase-dead AKT (KD-AKT) reduced $\mathrm{ER} \alpha$ levels (Figure $4 \mathrm{E}$ ). It is possible that PI3kinase-mediated destabilisation of $\mathrm{ER} \alpha$ involves AKT-dependent phosphorylation of $\mathrm{ER} \alpha$ followed by activation-coupled degradation. Our repeated attempts to establish MDA-MB-231 cells overexpressing $\mathrm{ER} \alpha$ mutants that cannot be phosphorylated by cyclin A/cdk2 (S102N,104P,106A), MAPK/cdk7 (S118A), AKT/RSK (S167A), PKA (S236A) or SRC (Y537F) were not successful. In transient transfection assays, phosphorylation-defective mutants were always expressed at a higher level than wild-type ER $\alpha$ (although expressed from a same promoter), suggesting that phosphorylation-defective mutants are more stable than wild-type $\mathrm{ER} \alpha$ (data not shown).

\section{Prolonged exposure of ER $\alpha$-overexpressing cells to TNF $\alpha$ leads to loss of transrepression, which can be reversed partially by LY294002}

To determine the consequences of stabilisation of ER $\alpha$ by LY294002 on transrepression, we treated parental and ER $\alpha$ overexpressing cells with TNF $\alpha$ for $16 \mathrm{~h}$ or 3 days and measured IL-6 expression levels. Interleukin- 6 expression in ER $\alpha-8$ cells was lower than in parental cells after $16 \mathrm{~h}$ of TNF $\alpha$ treatment (Figure 5). However, IL-6 expression was similar in both LxSN23 and ER $\alpha-8$ cells after 3 days of TNF $\alpha$ treatment. Interestingly, LY294002 was more effective in reducing TNF $\alpha$-inducible IL- 6 expression in ER $\alpha$ 8 cells compared to LxSN23 cells. Similar results were obtained in ER $\alpha-6$ cells. Note that LY294002 had no effect on TNF $\alpha$-inducible expression of TRAF-1. Thus, inhibition of TNF $\alpha$-inducible IL- 6 expression by LY294002 is less likely due to reduction in AKT/ PKB-mediated activation of NF- $\kappa \mathrm{B}$ or toxicity. We propose that LY294002 reduces TNF $\alpha$-inducible IL-6 expression in ER $\alpha$-overexpressing cells by enhancing transrepression function of ER $\alpha$. In contrast to enhanced transrepression, LY294002 reduced transactivation by $\mathrm{ER} \alpha$ (data not shown, Kishimoto and Nakshatri, submitted). Surprising specificity of LY294002 in inhibiting IL-6 but not TRAF-1 expression is encouraging as inhibitors with similar properties can be used to reduce invasion of breast cancer cells, more so of ER $\alpha$-positive cancer cells, by specifically reducing IL-6 expression.

\section{DISCUSSION}

In this report, we show that the $\mathrm{ER} \alpha$ protein level in breast cancer cells is regulated by TNF $\alpha$ and PI3-kinase, which has important implications on the transrepression function of ER $\alpha$. Transrepression by ER $\alpha$ is believed to be responsible for reducing invasion and metastasis of $\mathrm{ER} \alpha$-positive breast cancers (Platet et al, 2000). Repression of gene expression appears to be a major function of $\mathrm{ER} \alpha$ as recent studies show that among $\sim 400$ genes regulated by $\mathrm{ER} \alpha$ in MCF-7 cells, $\sim 70 \%$ of them are downregulated (Frasor et al, 2003). By lowering the $\mathrm{ER} \alpha$ protein level, TNF $\alpha$ and PI3kinase can overcome transrepression by $\mathrm{ER} \alpha$, thus promoting

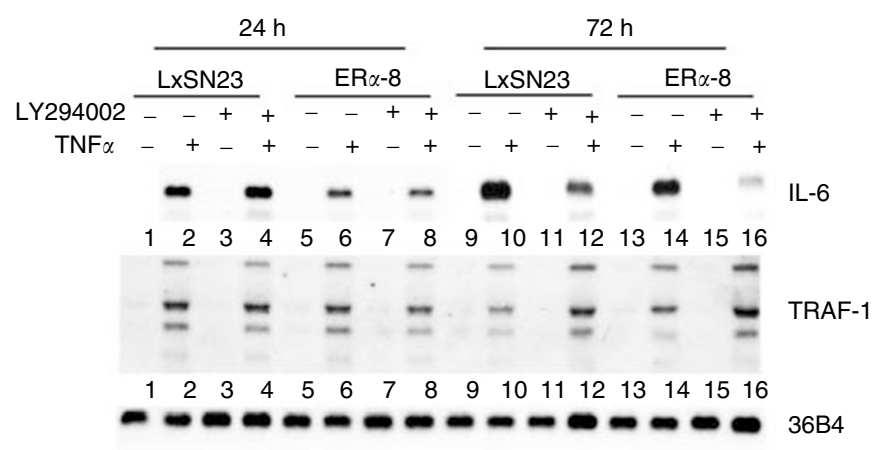

$\begin{array}{llllllllllllllll}1 & 2 & 3 & 4 & 5 & 6 & 7 & 8 & 9 & 10 & 11 & 12 & 13 & 14 & 15 & 16\end{array}$

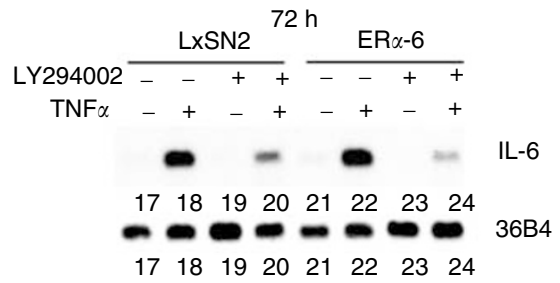

Figure 5 LY294002 inhibits TNF $\alpha$-induced IL-6 but not TRAF-I expression. Cells were treated with TNF $\alpha$ for $16 \mathrm{~h}$ or 3 days with or without LY294002. The media was changed daily with the addition of fresh TNF $\alpha$ and LY294002. Interleukin-6 and TRAF-I expression levels were measured by Northern analysis.

invasion and metastasis of breast cancers. Recent molecular profiling data with patient samples is consistent with the above observation. Patients with lower levels of ER $\alpha$ protein in their tumours have shorter disease-free survival rates than patients with higher levels of $\mathrm{ER} \alpha$ in their tumours (Sorlie et al, 2001). It is interesting that PI3-kinase levels are higher in highly invasive and metastatic breast cancer cell line MDA-MB-231 cells compared to nonmetastatic MCF-7 cells (Sliva et al, 2002), which can explain for LY294002-induced stabilisation of ER $\alpha$ in MDA-MB-231 cells overexpressing ER $\alpha$. Although our efforts to generate MCF-7 and MDA-MB-231 cells lacking PI3-kinase using siRNA technique were not successful, the failure of other kinase inhibitors including PD98059, PP2 and apigenin to alter the stability of ER $\alpha$ suggests that specific inhibition of PI3-kinase is responsible for LY294002induced stabilisation of ER $\alpha$. The PI3-kinase pathway appears to be involved in destabilisation of $\mathrm{ER} \alpha$ by TNF $\alpha$ but not E2, as LY294002 inhibited TNF $\alpha$-induced but not E2-induced degradation of ER $\alpha$ in MCF-7 cells (Figure 4). Our results differ to some extent from a recent report, which showed enhanced turnover of unliganded and liganded ER $\alpha$ in MCF-7 cells treated overnight with LY294002 (Marsaud et al, 2003). Authors suggested that PI3kinase activity is required for stabilisation of ER $\alpha$ in MCF-7 cells. Some of the effect of LY294002 on ER $\alpha$ protein level in MCF-7 cells could be at the level of $\mathrm{ER} \alpha$ transcription from the endogenous promoter as we also observed similar decrease in ER $\alpha$ protein in MCF-7 cells treated with LY294002. However, this is not the case when $\mathrm{ER} \alpha$ is expressed through a heterologous promoter as LY294002 stabilised ER $\alpha$ in MDA-MB-231 derivatives ER $\alpha-6$ and ER $\alpha-8$ cells (Figure $4 \mathrm{~A}$ ). Several recent studies suggest that data generated using LY294002 alone should be interpreted cautiously. For example, LY294002 inhibits both PI3-kinase and casein kinase II at same concentration (Davies et al, 2000). LY294002 has been shown to bind to the LBD of ER $\alpha$ and inhibit its activity (Pasapera Limon et al, 2003). To ensure a direct role for PI3-kinase in destabilisation of $\mathrm{ER} \alpha$, we determined the effect of overexpression of constitutively active PI3-kinase on ER $\alpha$ protein levels in MCF-7 cells. PI3-kinase reduced $\mathrm{ER} \alpha$ protein level in these cells (Figure 4E). 
A major implication of this study is on sensitivity of breast cancer cells to chemotherapy. Interleukin-6 has been shown to increase motility and confer multidrug resistance to breast cancer cells (Tamm et al, 1991; Conze et al, 2001). By reducing basal and/or TNF $\alpha$-induced IL-6 expression, ER $\alpha$ can reduce multidrug-resistant growth of breast cancer cells. Consistent with this possibility, in preliminary studies, we have observed increased sensitivity of ER $\alpha$-overexpressing MDAMB-231 cells to doxorubicin (data not shown). PI3-kinase inhibitors may further enhance the sensitivity of ER $\alpha$-expressing cells to chemotherapy by stabilising $\mathrm{ER} \alpha$. We have recently observed inhibition of the transactivation function of $\mathrm{ER} \alpha$ in tamoxifen-resistant breast cancer cells by PI3-kinase inhibitors (Kishimoto and Nakshatri, submitted). From these results, we propose that PI3-kinase inhibitors have the potential to overcome the multidrug resistance of ER $\alpha$-positive breast cancers by simultaneously increasing transrepression and reducing transactivation by $\mathrm{ER} \alpha$.

How TNF $\alpha$ and PI3-kinase promote degradation of ER $\alpha$ remains to be determined. Although TNF-induced degradation of $\mathrm{ER} \alpha$ has been reported, to our knowledge, this is the first report demonstrating a role for PI3-kinase in ER $\alpha$ degradation (Danforth and Sgagias, 1993). Phosphatidylinositol-3-kinase has recently been shown to be required for degradation of $\beta$-arrestin- 1 in response to chronic insulin treatment (Dalle et al, 2002). It is possible that TNF $\alpha$ and PI3-kinase induces the expression of a protein that targets $\mathrm{ER} \alpha$ for proteosome-mediated degradation or it may induce the activity of proteosomal subunits, which alters the specificity of the proteosome. In this regard, it has been shown that TNF $\alpha$ increases ubiquitin-conjugating activity by increasing the expression of $\mathrm{UbcH} 2$ through $\mathrm{NF}-\kappa \mathrm{B}$ (Li et al, 2003). The other possibility is that $\mathrm{TNF} \alpha$ alters the NEDD8 pathway, which has recently been shown to be involved in ER $\alpha$ degradation (Fan et al, 2003). Peroxisome proliferator-activated receptor gamma (PPAR $\gamma)$ and aryl hydrocarbon receptor also promote proteosomal degradation of $\mathrm{ER} \alpha$ (Qin et al, 2003; Wormke et al, 2003). It is possible that $\mathrm{TNF} \alpha$ utilises these receptors to promote ER $\alpha$ degradation. In this regard, kinetics and degree of TNF and aryl hydrocarbon receptor-induced degradation of $\mathrm{ER} \alpha$ are similar. The other possibility is that $\operatorname{TNF} \alpha$, like IFN $\alpha$, induces the replacement of proteosomal subunits, resulting in altered proteolytic specificity (Hisamatsu et al, 1996).

Although interaction between NF- $\kappa \mathrm{B}$ and $\mathrm{ER} \alpha$ was reported about 8 years ago (Stein and Yang, 1995), how that interaction leads to either transactivation or transrepression is not known. Initial studies suggested that competition for limiting coactivators is responsible for transrepression. However, subsequent studies by Parker's group and this study with a mutant ER $\alpha$ rule out coactivator competition as being the primary mechanism of transrepression, at least in breast cancer cells (Sheppard et al, 1999; Harnish et al, 2000; Valentine et al, 2000). Also, our studies show that not all NF- $\kappa$ B-regulated genes are transrepressed by $\mathrm{ER} \alpha$, which suggests that transrepression involves specific promoter context. There may be similarity in transrepression by GR and ER $\alpha$. Expression of IL-8 upon TNF $\alpha$ stimulation involves $\mathrm{NF}-\kappa \mathrm{B}$-dependent assembly of the transcription preinitiation complex followed by phosphorylation of the RNA polymerase II carboxyl terminal domain. Glucocorticoid receptor has been shown to interfere with phosphorylation of the RNA polymerase II carboxyl terminal domain without interfering with the preinitiation complex formation (Nissen and Yamamoto, 2000). Transrepression by GR in some instances involves corecruitment of the coactivator molecule GRIP1, and the coactivators SRC-1 and SRC-3 cannot substitute this function of GRIP1 (Rogatsky et al, 2002). Promoter specificity in ER $\alpha$-mediated transrepression may also involve a similar mechanism.

\section{ACKNOWLEDGEMENTS}

We thank SH Boswell, $\mathrm{P}$ Chambon, $\mathrm{K}$ Cornetta and $\mathrm{R}$ Ross for various reagents. We also thank Hui Lin Chua for a critical reading of the manuscript. This work is supported by grants from American Cancer Society (RPG-00-122-01-TBE) and National Institutes of Health (R01CA89153) to HN.

\section{REFERENCES}

Ali S, Coombes RC (2002) Endocrine-responsive breast cancer and strategies for combating resistance. Nat Rev Cancer 2: 101-112

Ali S, Metzger D, Bornert JM, Chambon P (1993) Modulation of transcriptional activation by ligand-dependent phosphorylation of the human oestrogen receptor A/B region. $E M B O J$ 12: $1153-1160$

Ali SH, O'Donnell AL, Balu D, Pohl MB, Seyler MJ, Mohamed S, Mousa S, Dandona P (2001) High levels of oestrogen receptor-alpha in tumorigenesis: inhibition of cell growth and angiogenic factors. Cell Prolif 34: $223-$ 231

Blobel GA, Sieff CA, Orkin SH (1995) Ligand-dependent repression of the erythroid transcription factor GATA- 1 by the estrogen receptor. Mol Cell Biol 15: 3147-3153

Campbell RA, Bhat-Nakshatri P, Patel NM, Constantinidou D, Ali S, Nakshatri H (2001) PI3-kinase/AKT-mediated activation of estrogen receptor alpha: a new model for anti-estrogen resistance. J Biol Chem 276: $9817-9824$

Cerillo G, Rees A, Manchanda N, Reilly C, Brogan I, White A, Needham M (1998) The oestrogen receptor regulates NFkappaB and AP-1 activity in a cell-specific manner. J Steroid Biochem Mol Biol 67: 79-88

Conze D, Weiss L, Regen PS, Bhushan A, Weaver D, Johnson P, Rincon M (2001) Autocrine production of interleukin 6 causes multidrug resistance in breast cancer cells. Cancer Res 61: 8851-8858

Critchfield JW, Coligan JE, Folks TM, Butera ST (1997) Casein kinase II is a selective target of HIV-1 transcriptional inhibitors. Proc Natl Acad Sci USA 94: $6110-6115$

Dalle S, Imamura T, Rose DW, Worrall DS, Ugi S, Hupfeld CJ, Olefsky JM (2002) Insulin induces heterologous desensitization of G-protein- coupled receptor and insulin-like growth factor I signaling by downregulating beta-arrestin-1. Mol Cell Biol 22: 6272-6285

Danforth Jr DN, Sgagias MK (1993) Tumour necrosis factor-alpha modulates oestradiol responsiveness of MCF-7 breast cancer cells in vitro. I Endocrinol 138: $517-528$

Davies SP, Reddy H, Caivano M, Cohen P (2000) Specificity and mechanism of action of some commonly used protein kinase inhibitors. Biochem 351: $95-105$

Di Croce L, Okret S, Kersten S, Gustafsson JA, Parker M, Wahli W, Beato M (1999) Steroid and nuclear receptors. Villefranche-sur-Mer, France, May 25-27, 1999. EMBO J 18: 6201-6210

Dong L, Wang W, Wang F, Stoner M, Reed JC, Harigai M, Samudio I, Kladde MP, Vyhlidal C, Safe S (1999) Mechanisms of transcriptional activation of bcl-2 gene expression by 17beta-estradiol in breast cancer cells. J Biol Chem 274: 32099-32107

Evans MJ, Lai K, Shaw LJ, Harnish DC, Chadwick CC (2002) Estrogen receptor alpha inhibits IL-1beta induction of gene expression in the mouse liver. Endocrinology 143: 2559-2570

Fan M, Bigsby RM, Nephew KP (2003) The NEDD8 pathway is required for proteasome-mediated degradation of human estrogen receptor (ER)alpha and essential for the antiproliferative activity of ICI 182780 in ERalpha-positive breast cancer cells. Mol Endocrinol 17: 356-365

Filardo EJ, Quinn JA, Bland KI, Frackelton Jr AR (2000) Estrogen-induced activation of Erk-1 and Erk-2 requires the G protein-coupled receptor homolog, GPR30, and occurs via trans-activation of the epidermal growth factor receptor through release of HB-EGF. Mol Endocrinol 14: $1649-1660$ 
Frasor J, Danes JM, Komm B, Chang KC, Lyttle CR, Katzenellenbogen BS (2003) Profiling of estrogen up- and down-regulated gene expression in human breast cancer cells: insights into gene networks and pathways underlying estrogenic control of proliferation and cell phenotype. Endocrinology 144: 4562 - 4574

Fujita N, Jaye DL, Kajita M, Geigerman C, Moreno CS, Wade PA (2003) MTA3, a Mi-2/NuRD complex subunit, regulates an invasive growth pathway in breast cancer. Cell 113: 207-219

Gaub MP, Bellard M, Scheuer I, Chambon P, Sassone-Corsi P (1990) Activation of the ovalbumin gene by the estrogen receptor involves the fos-jun complex. Cell 63: 1267-1276

Glass CK, Rosenfeld MG (2000) The coregulator exchange in transcriptional functions of nuclear receptors (in process citation). Genes Dev 14: 121 141

Harnish DC, Scicchitano MS, Adelman SJ, Lyttle CR, Karathanasis SK (2000) The role of CBP in estrogen receptor cross-talk with nuclear factor-kappaB in HepG2 cells. Endocrinology 141: 3403-3411

Hisamatsu H, Shimbara N, Saito Y, Kristensen P, Hendil KB, Fujiwara T, Takahashi E, Tanahashi N, Tamura T, Ichihara A, Tanaka K (1996) Newly identified pair of proteasomal subunits regulated reciprocally by interferon gamma. J Exp Med 183: 1807-1816

Horwitz KB, Jackson TA, Bain DL, Richer JK, Takimoto GS, Tung L (1996) Nuclear receptor coactivators and corepressors. Mol Endocrinol 10: $1167-1177$

Jilka RL, Hangoc G, Girasole G, Passeri G, Williams DC, Abrams JS, Boyce B, Broxmeyer H, Manolagas SC (1992) Increased osteoclast development after estrogen loss: mediation by interleukin-6. Science 257: 88-91

Lee H, Bai W (2002) Regulation of estrogen receptor nuclear export by ligand-induced and p38-mediated receptor phosphorylation. Mol Cell Biol 22: $5835-5845$

Le Goff P, Montano MM, Schodin DJ, Katzenellenbogen BS (1994) Phosphorylation of the human estrogen receptor. Identification of hormone-regulated sites and examination of their influence on transcriptional activity. $J$ Biol Chem 269: 4458-4466

Li YP, Lecker SH, Chen Y, Waddell ID, Goldberg AL, Reid MB (2003) TNFalpha increases ubiquitin-conjugating activity in skeletal muscle by upregulating UbcH2/E220k. FASEB J 17: 1048 - 1057

Lonard DM, Nawaz Z, Smith CL, O'Malley BW (2000) The 26S proteasome is required for estrogen receptor-alpha and coactivator turnover and for efficient estrogen receptor-alpha transactivation. Mol Cell 5: $939-948$

Ma Z, Webb DJ, Jo M, Gonias SL (2001) Endogenously produced urokinasetype plasminogen activator is a major determinant of the basal level of activated ERK/MAP kinase and prevents apoptosis in MDA-MB-231 breast cancer cells. J Cell Sci 114: 3387-3396

Mangelsdorf DJ, Thummel C, Beato M, Herrlich P, Schutz G, Umesono K, Blumberg B, Kastner P, Mark M, Chambon P, Evans RM (1995) The nuclear receptor superfamily: the second decade. Cell 83: 835-839

Marquez DC, Pietras RJ (2001) Membrane-associated binding sites for estrogen contribute to growth regulation of human breast cancer cells. Oncogene 20: $5420-5430$

Marsaud V, Gougelet A, Maillard S, Renoir JM (2003) Various phosphorylation pathways, depending on agonist and antagonist binding to endogenous estrogen recepto. Mol Endocrinol 17: 2013-2027

Metivier R, Stark A, Flouriot G, Hubner MR, Brand H, Penot G, Manu D, Denger S, Reid G, Kos M, Russell RB, Kah O, Pakdel F, Gannon F (2002) A dynamic structural model for estrogen receptor-alpha activation by ligands, emphasizing the role of interactions between distant $\mathrm{A}$ and $\mathrm{E}$ domains. Mol Cell 10: 1019-1032

Miller AD, Rosman GJ (1989) Improved retroviral vectors for gene transfer and expression. Biotechniques 7: $980-990$

Muller A, Homey B, Soto H, Ge N, Catron D, Buchanan ME, McClanahan T, Murphy E, Yuan W, Wagner SN, Barrera JL, Mohar A, Verastegui E, Zlotnik A (2001) Involvement of chemokine receptors in breast cancer metastasis. Nature 410: $50-56$

Nakshatri H, Bhat-Nakshatri P, Martin DA, Goulet Jr RJ, Sledge Jr GW (1997) Constitutive activation of NF-kappaB during progression of breast cancer to hormone-independent growth. Mol Cell Biol 17: 3629-3639

Newton TR, Patel NM, Bhat-Nakshatri P, Stauss CR, Goulet Jr RJ, Nakshatri H (1999) Negative regulation of transactivation function but not DNA binding of NF-kappaB and AP-1 by IkappaBbeta1 in breast cancer cells. $J$ Biol Chem 274: $18827-18835$
Nissen RM, Yamamoto KR (2000) The glucocorticoid receptor inhibits NFkappaB by interfering with serine-2 phosphorylation of the RNA polymerase II carboxy-terminal domain. Genes Dev 14: 2314-2329

Paech K, Webb P, Kuiper GG, Nilsson S, Gustafsson J, Kushner PJ, Scanlan TS (1997) Differential ligand activation of estrogen receptors ERalpha and ERbeta at AP1 sites. Science 277: $1508-1510$

Pasapera Limon AM, Herrera-Munoz J, Gutierrez-Sagal R, Ulloa-Aguirre A (2003) The phosphatidylinositol 3-kinase inhibitor LY294002 binds the estrogen receptor and inhibits 17beta-estradiol-induced transcriptional activity of an estrogen sensitive reporter gene. Mol Cell Endocrinol 200: 199-202

Patel NM, Nozaki S, Shortle NH, Bhat-Nakshatri P, Newton TR, Rice S, Gelfanov V, Boswell SH, Goulet Jr RJ, Sledge Jr GW, Nakshatri H (2000) Paclitaxel sensitivity of breast cancer cells with constitutively active NFkappaB is enhanced by IkappaBalpha super-repressor and parthenolide. Oncogene 19: 4159-4169

Platet N, Cunat S, Chalbos D, Rochefort H, Garcia M (2000) Unliganded and liganded estrogen receptors protect against cancer invasion via different mechanisms. Mol Endocrinol 14: 999-1009

Pottratz ST, Bellido T, Mocharla H, Crabb D, Manolagas SC (1994) 17 betaEstradiol inhibits expression of human interleukin-6 promoter-reporter constructs by a receptor-dependent mechanism. J Clin Invest 93: $944-950$

Qin C, Burghardt R, Smith R, Wormke M, Stewart J, Safe S (2003) Peroxisome proliferator-activated receptor gamma agonists induce proteasome-dependent degradation of cyclin D1 and estrogen receptor alpha in MCF-7 breast cancer cells. Cancer Res 63: 958-964

Razandi M, Alton G, Pedram A, Ghonshani S, Webb P, Levin ER (2003) Identification of a structural determinant necessary for the localization and function of estrogen receptor alpha at the plasma membrane. $\mathrm{Mol}$ Cell Biol 23: $1633-1646$

Rogatsky I, Luecke HF, Leitman DC, Yamamoto KR (2002) Alternate surfaces of transcriptional coregulator GRIP1 function in different glucocorticoid receptor activation and repression contexts. Proc Natl Acad Sci USA 99: $16701-16706$

Rothe M, Wong SC, Henzel WJ, Goeddel DV (1994) A novel family of putative signal transducers associated with the cytoplasmic domain of the $75 \mathrm{kDa}$ tumor necrosis factor receptor. Cell 78: 681-692

Schroder J, Kahlke V, Staubach KH, Zabel P, Stuber F (1998) Gender differences in human sepsis. Arch Surg 133: 1200-1205

Sheppard KA, Rose DW, Haque ZK, Kurokawa R, McInerney E, Westin S, Thanos D, Rosenfeld MG, Glass CK, Collins T (1999) Transcriptional activation by NF-kappaB requires multiple coactivators. Mol Cell Biol 19: $6367-6378$

Simoncini T, Hafezi-Moghadam A, Brazil DP, Ley K, Chin WW, Liao JK (2000) Interaction of oestrogen receptor with the regulatory subunit of phosphatidylinositol-3-OH kinase. Nature 407: 538-541

Sliva D, Rizzo MT, English D (2002) Phosphatidylinositol 3-kinase and NFkappaB regulate motility of invasive MDA-MB-231 human breast cancer cells by the secretion of urokinase-type plasminogen activator. J Biol Chem 277: $3150-3157$

Sorlie T, Perou CM, Tibshirani R, Aas T, Geisler S, Johnsen H, Hastie T, Eisen MB, van de Rijn M, Jeffrey SS, Thorsen T, Quist H, Matese JC, Brown PO, Botstein D, Eystein Lonning P, Borresen-Dale AL (2001) Gene expression patterns of breast carcinomas distinguish tumor subclasses with clinical implications. Proc Natl Acad Sci USA 98: $10869-10874$

Stein B, Yang MX (1995) Repression of the interleukin-6 promoter by estrogen receptor is mediated by NF-kappa B and C/EBP beta. Mol Cell Biol 15: $4971-4979$

Tamm I, Cardinale I, Murphy JS (1991) Decreased adherence of interleukin 6-treated breast carcinoma cells can lead to separation from neighbors after mitosis. Proc Natl Acad Sci USA 88: 4414-4418

Valentine JE, Kalkhoven E, White R, Hoare S, Parker MG (2000) Mutations in the estrogen receptor ligand binding domain discriminate between hormone-dependent transactivation and transrepression. J Biol Chem 275: $25322-25329$

Wang RA, Mazumdar A, Vadlamudi RK, Kumar R (2002) P21-activated kinase-1 phosphorylates and transactivates estrogen receptor-alpha and promotes hyperplasia in mammary epithelium. EMBO J 21: 5437-5447 Wormke M, Stoner M, Saville B, Walker K, Abdelrahim M, Burghardt R, Safe S (2003) The aryl hydrocarbon receptor mediates degradation of estrogen receptor alpha through activation of proteasomes. Mol Cell Biol 23: 1843- 1855 